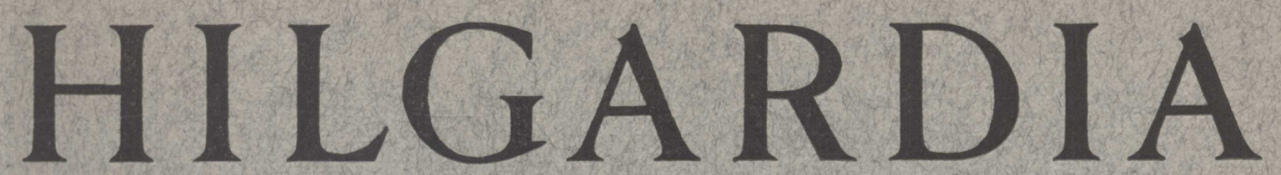

A Journal of Agricultural Science Publisbed by the California Agricultural Experiment Station

CONTENTS

DEVELOPMENTAL ANATOMY OF THE FLESHY STORAGE ORGAN OF DAUCUS CAROTA KATHERINE ESAU

\title{
STRUCTURE OF END WALLS IN DIFFERENTIATING VESSELS
}

KATHERINE ESAU and WM. B. HEWITT

\section{COMPARATIVE HISTOGENESIS OF} VEGETATIVE AND FLORAL APICES IN AMYGDALUS COMMUNIS, WITH SPECIAL REFERENCE TO THE CARPEL REID M. BROOKS 
STRUCTURE OF END WALLS IN

\section{DIFFERENTIATING VESSELS}

KATHERINE ESAU AND WM. B. HEWITT 



\title{
STRUCTURE OF END WALLS IN DIFFERENTIATING VESSELS ${ }^{1}$
}

\author{
KATHERINE ESAU ${ }^{2}$ AND WM. B. HEWITT ${ }^{3}$
}

\section{INTRODUCTION}

THE SENIOR WRITER's observations on the method of establishment of continuity between vessel segments in celery (Esau, 1936b) ${ }^{4}$ contradicted Priestley and his associates' $(1935 ; 1938$, p. 348) interpretation of this phenomenon in other plants. It seemed desirable, therefore, to survey the literature for references on vessel ontogeny and to check the results obtained with celery by using some other plants. Moreover, addition of microchemical tests to the morphologic observations appeared pertinent. These enlarged studies on the nature and longevity of vessel end walls are described in the present paper.

\section{REVIEW OF LITERATURE}

The development of continuous xylem tubes by perforation or complete removal of end walls in series of superposed cells has been recorded by early workers (Treviranus, 1835; Mirbel, 1837; and others). Among these, von Mohl $(1845 a, 1845 b, 1849)$ and Crüger (1855) observed that the continuity between the vessel elements was established after the development of the secondary thickenings $\mathrm{s}^{5}$ on the longitudinal walls and after the formation of the rim of secondary nature on the end walls. Many of the subsequent workers also observed that the end walls were perforated during the final stages of vessel differentiation, that is, after the vessel elements attained their mature diameter and maximum wall thickness (de Bary, 1884, p. 165; Strasburger, 1882, p. 81; Lange, 1891; Flach, 1924 ; Eames and MacDaniels, 1925, p. 151; Duerden, 1934 ; Esau, $1936 b)$.

Hartig (1853) and Flach (1924) reported that the dissolution of the

${ }^{1}$ Received for publication December 12, 1939.

${ }^{2}$ Assistant Professor of Botany and Assistant Botanist in the Experiment Station.

${ }^{3}$ Instructor in Plant Pathology and Junior Plant Pathologist in the Experiment Station.

"See "Literature Cited" for complete data on citations, which are referred to in the text by author and date of publication.

${ }^{5}$ The terms secondary thickening or secondary wall are used throughout this paper to denote the rings, spirals, reticulae, or the more extensive pitted layers of wall material, that are laid over the continuous (except for the plasmodesmata perforations), commonly thin wall of the expanded vessel mother cell. The continuous wall is referred to as the primary wall. 
end walls was a gradual process beginning in one spot-in the middle of the wall, according to Flach-and spreading thence to other parts of the wall. The protoplasts of the individual vessel elements disintegrated approximately at the same time as the end walls (Hartig, 1853; Flach, 1924 ; Eames and MacDaniels, 1925, p. 151, fig. 75 ; Esau, 1936b). Workers noted that walls undergoing disintegration were rarely encountered in preparations (Flach, 1924; Duerden, 1934; Esau, 1936b).

Long before the end wall breaks down it becomes much thicker than the primary longitudinal walls (Strasburger, 1882, p. 81; Flach, 1924; Esau, 1936b). If only a portion of the end wall is removed the thickening is restricted to this portion (Esau, 1936b). Strasburger (1882, p. 81) and Flach (1924) interpreted this thickening as swelling. According to Flach, during this swelling the hemicelluloses of the end wall are converted into pectic materials. Pure cellulose was said to be absent in the end walls.

Eames and MacDaniels (1925, p. 151, fig. 75c) depicted the end-wall thickening in differentiating vessels as secondary; Flach (1924) and Esau (1936b) regarded it as primary.

In contrast to the writers considered above, Priestley and his coworkers $(1935,1938$, p. 348 ) advance the concept that end walls in vessels of woody angiosperms are destroyed during the expansion of the mother cells. These authors have not seen fragments of such walls, but suggest that the walls break in the middle and then rapidly retract toward the periphery, and thus form a thick rim around the orifice. Their figures 2 and 3 (Priestley, Scott, and Malins, 1935) supposedly show such rims. In figure 3, however, the "rim" resembles the thickened lenticular end wall described by Esau (1936b, plates $2, A$, and 4, $A-C$ ). In the same figure one might suspect the presence of two fragments of the end wall hanging down into the lower cell, but these structures are also labeled as rim.

Although, according to Priestley, Scott, and Malins (1935, p. 45, 53), the end wall is perforated early in vessel development, the protoplasts of the superposed segments do not mingle, for "thin, mucilaginous pectin films" often remain stretched across the opening. The structures labeled as films in plate 1, figures 2 and 3, of these authors, however, appear like end walls cut on slant or torn in cutting.

References to breakdown of end walls occur also in the group of papers describing a multinucleate phase in vessel development of some plants.

According to Kny (1886), in certain Dioscoreaceae and woody Liliaceae the very long tracheids of the secondary bundles of stems are formed from series of superposed cells in which transverse walls disintegrate. 
The phenomenon is said to occur before secondary walls are laid down and while the protoplasts are alive. A multinucleate condition results from fusion of protoplasts.

Although certain later workers (Wieler, 1889 ; and others) accepted Kny's interpretation, others did not. Among the latter Röseler (1889), having reinvestigated the Liliaceae used by Kny, concluded that the tracheids attain their length through gliding growth and that the multinucleate condition is only apparent; the nuclei belong to different radially superposed cells. Scott and Brebner (1893) and recently Cheadle (1937) agreed with Röseler that the tracheids arose from single uninucleate cells elongating by sliding growth.

Hill and Freeman (1903) described a multinucleate condition in young vessels of Dioscorea prehensilis and said it was produced by the obliteration of walls between the superposed cells. Pirotta and Buscalioni (1898), however, reported that the vessel elements of Dioscoreaceae became multinucleate through repeated nuclear divisions and that the perforation of the end walls occurred after the nuclei disintegrated. Němec (1910) agreed with this interpretation.

In the first of two articles on vessels of Ricinus, Scott (1935) reported that the young vessels became coenocytic through an early breakdown of transverse walls. The second paper (Scott, 1937, p. 71) implies that omission of cytokinesis in procambium cells causes the multinucleate condition.

The multinucleate vessel mother cells of Euphorbiaceae, including Ricinus, were previously considered by Smolák (1904). According to this worker, nuclei multiply without formation of cell walls and the vessel end walls are resorbed after the secondary layers appear on the longitudinal walls. Smolák's observations were confirmed by Němec (1910, p. 120-151).

In the writers' opinion, workers who place the establishment of continuity in a vessel at the end of its differentiation have furnished more convincing data to support their contention than those who suggest that the perforation of the end wall occurs while the vessel mother cell is expanding. The observations here recorded further show the persistence of terminal walls in differentiating vessels.

\section{MORPHOLOGY OF THE END WALLS IN DIFFERENTIATING VESSELS}

The characteristics and behavior of vessel end walls were studied in several herbaceous angiosperms-Cucurbita pepo, Zea mays, Nicotiana tabacum, Daucus carota, and Beta vulgaris. 
Cucurbita belongs to the type of plants in which the differentiating vessels expand very rapidly, attaining much larger diameters than the meristematic cells from which they arose. Plate $1, A$, illustrates the striking contrast in size between the cambium cells and the vessels.

The enlarging vessels, of course, affect the arrangement of adjacent cells; the latter are stretched transversely and are also pulled apart. The separating cells remain, however, partly attached to each other by means of cell prolongations that appear like protuberances or arms (plate 3, $C$ ). Zimmermann (1922) has amply illustrated the bizarre shapes encountered among these cells.

Through the separation of adjacent cells the vessel is brought into eontact with new cells (Velten, 1875; Priestley, Scott, and Malins, 1935; Esau, 1936a; and others).

Regardless of the rapid and immense expansion of the large vessels of Cucurbita, the end walls do not break down during this growth. On the contrary, after the completion of vessel enlargement their transverse walls are thicker and therefore more prominent than the longitudinal walls (plate $2, B$ and $C$ ). At this time the end walls appear tightly stretched; the longitudinal walls are pulled in at the transverse partitions so that the vessel elements appear constricted at the ends.

Plate 2, $C$, shows that the end walls are much thinner at their margins than in the median portion. These margins remain intact in mature vessels and are covered by rims of secondary wall material. In the relatively narrow celery vessels studied previously (Esau, 1936b) the end walls were thickest in the middle and tapered gradually toward the margins so that the walls resembled biconvex lenses. This shape of the end walls is apparently characteristic of vessels of narrow diameter and was observed in the primary xylem of Beta, Daucus, and Nicotiana used in this study.

The end walls persist until secondary layers develop on the longitudinal walls. The Cucurbita vessel mother cells shown in plate $2, A$, had secondary walls with bordered pits; but their transverse walls and protoplasts were still intact. In this photograph seven transverse end walls appear in section; the other five are somewhat tilted, appearing like thin films.

In Zea mays the expansion of the two large pitted metaxylem vessels is also rather marked. In the vascular bundle from a stem of maize in plate $1, B$, these vessels had no secondary walls but were fully expanded. One of the two large vessels showed the transverse end wall covered with cytoplasm.

Plate 4, $A$ and $B$, illustrates portions of metaxylem vessels of maize in 
longitudinal sections. The element in $A$ had secondary thickenings on longitudinal walls, but was eut mostly through parts of walls that bore no pits. The primary end wall in this view is as thick as the secondary longitudinal walls. The rims seen in section right and left on the transverse wall are secondary and are rather sharply set off from the primary end wall.

Traces of deeply stained material appear in place of the terminal wall in plate $4, B$. In contrast to the cells in $A$, those in $B$ are free of cytoplasm.

In the vessel cells in $B$, bordered pits are perceptible in the longitudinal walls and occur also in the rather wide rim.

Plate $3, B$, shows longitudinally a portion of a young pitted vessel from the secondary xylem of Nicotiana. This vessel had reached its ultimate width and had secondary walls. The part of the oblique end wall that would have been removed upon maturation of the vessel is black in plate $3, \boldsymbol{B}$. Because it was cut somewhat on slant, its thickness is exaggerated.

The section in plate $3, B$, was stained with safranin and anilin blue and then photographed through Wratten filters $25 \mathrm{~A}$ and 52 naphtol green. In the photograph the lignified secondary walls, which were stained pink, came out faintly gray. The pit-closing membranes and the primary portion of the end wall were stained blue and appear black.

Only elements of the primary xylem were examined in the sugar beet and carrot. These two plants gave views very similar to those obtained with the celery (Esau, 1936b).

\section{MICROCHEMICAL AND OPTICAL TESTS OF THE END WALLS}

The primary purpose of the microchemical and optical tests was to determine whether or not cellulose was present in those vessel walls that disintegrate when the vessels mature. These studies were made by the methods described by Rawlins (1933). Before the tests, the material was imbedded in paraffin, sectioned with a microtome, 8 to 10 microns thick, mounted on slides, and treated with xylene and alcohol. The vessel end walls of all the three plants used in these studies-Cucurbita, Zea, and Nicotiana-showed similar reactions.

Cellulose is doubly refractive, or anisotropic when observed between crossed Nicol prisms. A transverse or oblique partition between two vessel elements consists of two peripheral anisotropic layers and a median isotropic (not doubly refractive) layer. The anisotropic layers are present before and after expansion of the vessel element. A treatment of the 
sections for 15 to 20 minutes in water just below the boiling point enhanced the prominence of the doubly refractive layers (plate $4, C$ ). They became particularly bright after the sections were stained with congo red (plate $4, D$ ) or with iodine in potassium iodide ${ }^{6}$ and duPont Rayon Bordeaux B.

Either zinc-chlor-iodide or $\mathrm{I}_{2} \mathrm{KI}$ followed by 65 per cent $\mathrm{H}_{2} \mathrm{SO}_{4}$ stains the cellulose blue; the lignified and the suberized walls yellow. Both reagents stain the anisotropic layers blue, the zinc-chlor-iodide giving a more intense coloration than the $\mathrm{I}_{2} \mathrm{KI}$. Plate $3, A$, shows a portion of Zea vessel treated with zinc-chlor-iodide. The blue layers appear as thin dark lines on either side of the thick transverse partition.

Cellulose is soluble in either cuprammonia solution or in 72 per cent $\mathrm{H}_{2} \mathrm{SO}_{4}$. These reagents removed the anisotropic layers of the vessel end walls but left the isotropic substance.

Sections exposed to alternate treatments with chlorine water and hot 2 per cent sodium sulfite-a treatment that dissolves lignin and the intercellular material but leaves the cellulose-left the two anisotropic layers of the vessel end walls intact. The isotropic layer was apparently removed ; it could not be detected by staining with ruthenium red, hematoxylin, or congo red after the treatment.

Under certain conditions hemicellulose shows anisotropy. It is, however, soluble in dilute mineral acids and alkalies. After treatment with either 3 per cent $\mathrm{KOH}$ or 6 per cent $\mathrm{HCl}$ at room temperature the end walls of the vessel elements swelled but neither the anisotropic nor the isotropic layer was dissolved.

The entire end wall of a vessel element stains red with ruthenium red. This staining reaction probably indicates the presence of the so-called "pectic substances" in both the isotropic and the anisotropic layers. After prolonged treatment of sections in hot 12 per cent $\mathrm{HCl}$ the anisotropic layers stained faintly with ruthenium red, brightly with congo red. Since the isotropic layer did not stain it evidently was removed by the acid treatment. These results further indicate that the materials staining red with ruthenium red are pectic in nature.

The optical and chemical properties of the end walls of the vessel elements were the same before and after the lignification of the secondary longitudinal walls. The presence of lignin was determined by the Mäule test. At all times the end walls reacted negatively in the Mäule test, that is, they showed no lignification.

The doubly refractive layers of the end walls show optical and microchemical reactions similar to those of the not yet lignified longitudinal

\footnotetext{
- This procedure was suggested by Professor I. W. Bailey, Harvard University.
} 
walls of the vessel elements and the primary walls of the adjacent cells. The anisotropy of these two layers evidently results from the presence of cellulose. They are here interpreted as the two primary walls of the two superposed vessel segments, and the isotropic layer is regarded as the intercellular substance, which is probably pectic in nature.

\section{SUMMARY}

The differentiating vessel elements of the herbaceous angiosperms here considered show intact end walls until the future vessel reaches its final diameter and develops secondary lignified layers on the longitudinal walls.

Two superposed vessel elements are separated from each other by two cellulose layers-the two primary walls-cemented together by isotropic intercellular substance. 


\section{LITERATURE CITED}

BARY, A. DE.

1884. Comparative anatomy of the vegetative organs of the phanerogams and ferns. (English translation by F. O. Bower and D. H. Scott.) 659 p. Clarendon Press, Oxford.

Cheadle, V. I.

1937. Secondary growth by means of a thickening ring in certain monocotyledons. Bot. Gaz. 98:535-55.

CRÜGER, H.

1855. Westindische Fragmente. Sechstes Fragment. Zur Entwickelungsgeschichte der Zellenwand. Bot. Ztg. 13:601-13; 617-29.

DUERDEN, $\mathrm{H}$.

1934. On the occurrence of vessels in Selaginella. Ann. Bot. [London] 48:459-65.

EAMES, A. J., and L. H. MAcDaniels.

1925. An introduction to plant anatomy. 364 p. MeGraw-Hill Book Company, New York, N. Y.

ESAU, KATHERINE.

1936a. Ontogeny and structure of collenchyma and of vascular tissues in celery petioles. Hilgardia $10(11): 431-76$.

1936b. Vessel development in celery. Hilgardia $10(11): 479-88$.

FLACH, P.

1924. Cytologische Untersuchungen über die Gefässbildung bei Cucurbita pepo. Akad. der Wiss. Wien, Math.-Nat. Kl. Sitzber. Abt. 1, 133:265-90.

HARTig, TH.

1853. Ueber die Entwickelung des Jahrringes der Holzpflanzen. Bot. Ztg. 11:553$60 ; 569-79$.

Hill, T. G., and W. G. Freeman.

1903. The root-structure of Dioscorea prehensilis. Ann. Bot. [London] 17:415-24.

KNY, L.

1886. Ein Beitrag zur Entwickelungsgeschichte der "Tracheiden." Deut. Bot. Gesell. Ber. 4:267-76.

LANGE, TH.

1891. Beiträge zur Kenntnis der Entwicklung der Gefässe und Tracheiden. Flora 74 (n.s.49) : 393-434.

MiRBEL, B.

1837. Observations sur le cambium et sur quelques modes de formations utriculaires ou vasculaires dans les végétaux. Compt. Rend. Acad. Sci. 5:295301.

MoHL, Hugo von.

1845a. Einige Bemerkungen über den Bau der getüpfelten Gefässe. Vermischte Schriften botanischen Inhaltes. 442 p. Paper 21, p. 272-84. L. F. Fues, Tübingen, Germany.

1845b. Ueber den Bau des Palmenstammes. Vermischte Schriften botanischen Inhaltes. 442 p. Paper 11, p. 129-85. L. F. Fues, Tübingen, Germany.

1849. On the structure of the palm-stem. Reports and Papers in Botany. $514 \mathrm{p}$. Ray Society, London. 
NĚmec, B.

1910. Das Problem der Befruchtungsvorgänge und andere zytologische Fragen. 532 p. Gebrïder Borntraeger, Berlin.

PirotTa, R., and L. Buscalioni.

1898. Sulla presenza dei elementi vascolari multinucleati nelle Dioscoreacee. Ann. R. Inst. Bot. Roma $7: 237-54$.

Priestlex, J. H., and L. I. ScotT.

1938. An introduction to botany with special reference to the structure of the flowering plant. 615 p. Longmans, Green and Co., London.

Priestuey, J. H., L. I. ScotT, and M. E. Malins.

1935. Vessel development in the angiosperm. Leeds Phil. Soc. Proc. 3:42-54.

RAWLINS, T. E.

1933. Phytopathological and botanical research methods. $156 \mathrm{p}$. John Wiley and Sons, New York, N. Y.

RÖSELER, P.

1889. Das Dickenwachsthum und die Entwickelungsgeschichte der secundären Gefassbündel bei den baumartigen Lilien. Jahrb. f. Wiss. Bot. 20:292-348.

SCOTT, D. H., and G. BREBNer.

1893. On the secondary tissues in certain monocotyledons. Ann. Bot. [London] $7: 21-62$.

ScoTT, F M.

1935. The cytology of the differentiating spiral vessel in Ricinus communis. Science $82: 302$.

1937. Differentiation of the spiral vessels in Ricinus communis. Bot. Gaz. 99: 69-79.

SMOLÁK, JAROSLAV.

1904. O mnohojaderných buňkach Euphorbiacei. (On multinucleate cells of Euphorbiaceae.) Rozpr. České Akad. Cís. Františka Josefa (Ann. Czech Akad. Emp. Franz Joseph) Sec. II Math.-Biol. 13:1-14.

STRASBURGER, E.

1882. Ueber den Bau und das Wachsthum der Zellhäute. 264 p. Gustav Fischer, Jena.

Treviranus, L. C.

1835. Physiologie der Gewächse. Vol. 1. 570 p. Adolph Mareus, Bonn.

VELTEN, W.

1875. Ueber die Entwickelung des Cambium und N. J. C. Müller's Ideen über diesen Gegenstand. Bot. Ztg. $33: 809-14 ; 826-29 ; 841-45$.

WIELER. [No initial.]

1889. [No title.] Bot. Ztg. 47:701-06.

ZimmermanN, A.

1922. Die Cucurbitaceen. Part 1. Beiträge zur Anatomie und Physiologie. $204 \mathrm{p}$. Gustav Fischer, Jena. 

PLATES 


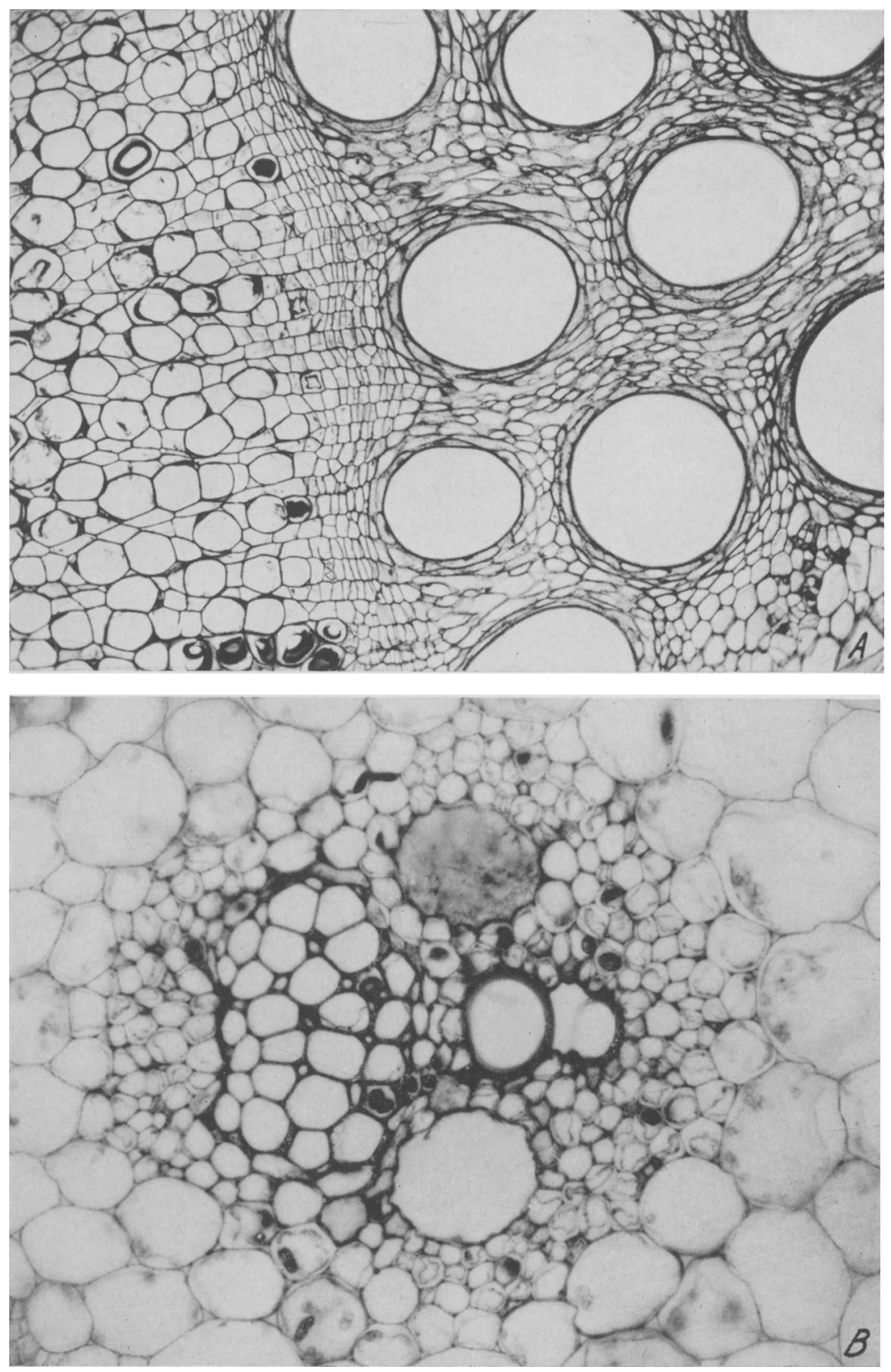

Plate 1.-A, Transverse section of part of a vascular bundle of Cucurbita showing phloem to the left, xylem to the right, and cambium between the xylem and phloem. $(\times 90)$.$B , Trans-$ verse section of a vascular bundle of $Z e a$ showing phloem to the left and xylem to the right. $(X$ 400.) Further explanation in the text. 

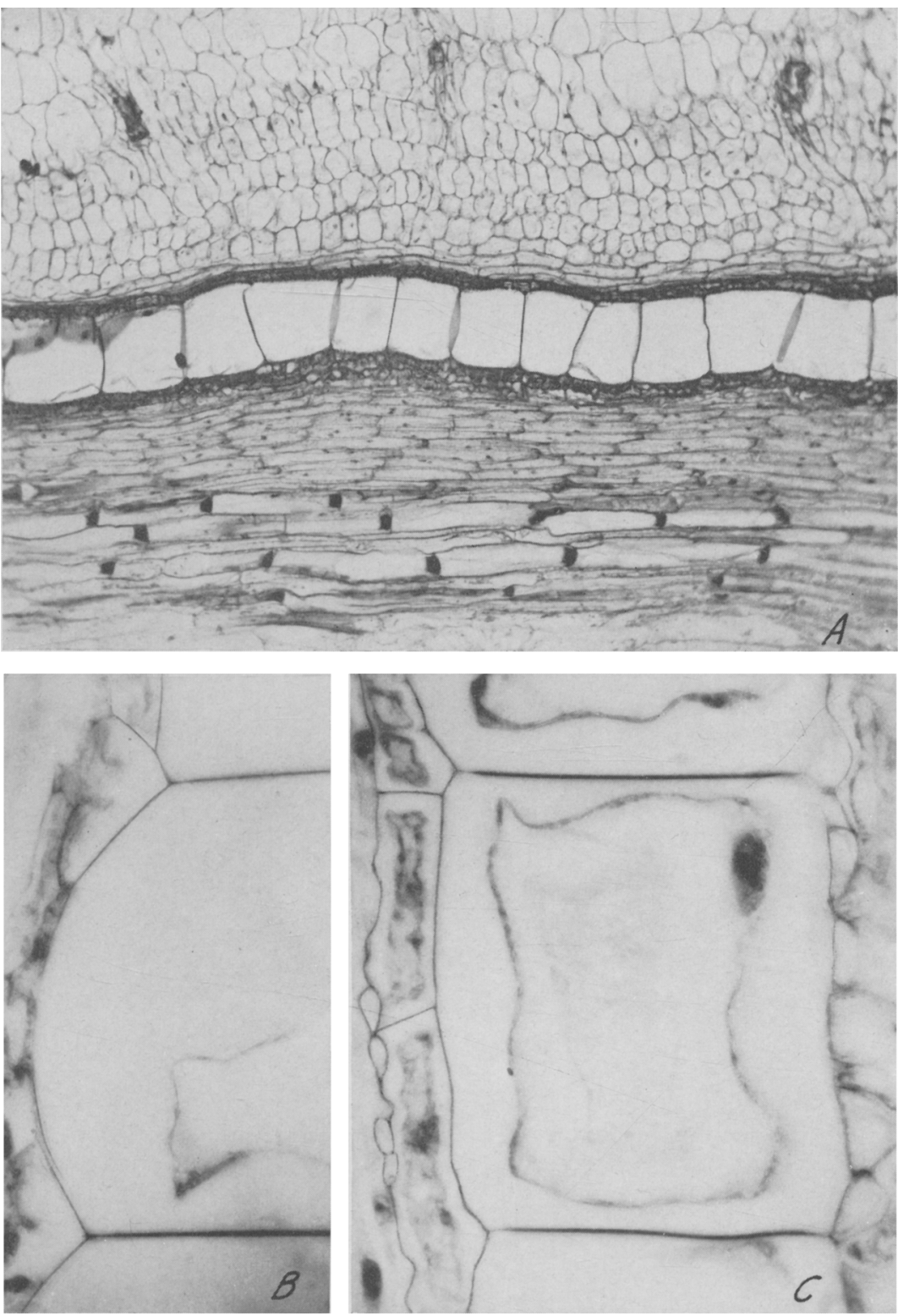

Plate 2.-Differentiating vessel elements of Cucurbita: A, longitudinal section of part of a vascular bundle showing phloem below and, above the phloem, a row of wide vessel segments with intact end walls $(\times 90) ; B$, portion of a vessel segment with thickened end walls; $C$, entire vessel element with protoplast and thickened transverse walls. ( $B$ and $C, \times 540$.) 

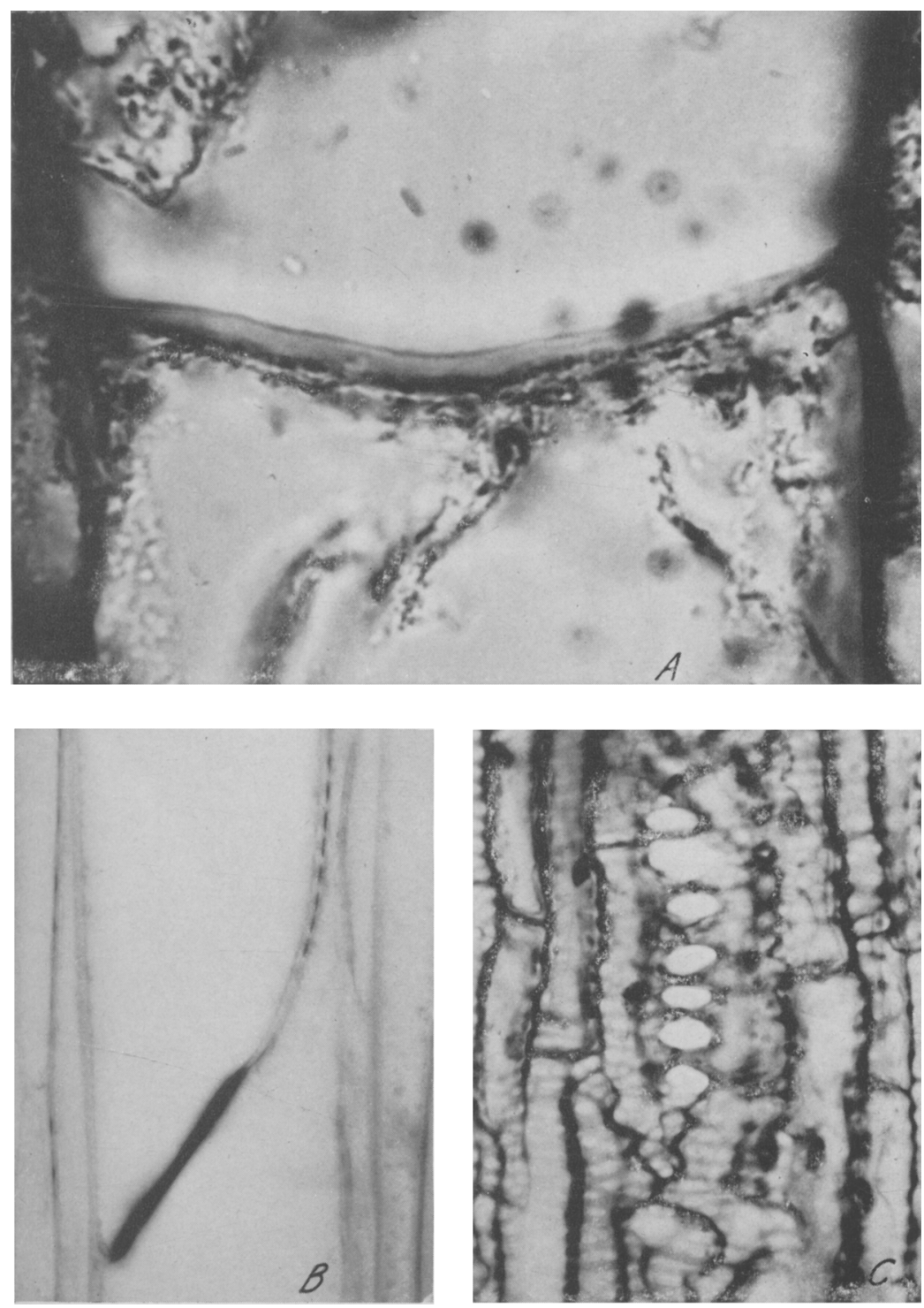

Plate 3.-A, Longitudinal section of a portion of a $Z e a$ vessel. The end wall has been treated with zinc-chlor-iodide and mounted in the same solution. The transverse wall is bordered on the upper and lower sides by dark lines, which were stained blue in the original preparation, whereas the rest of the wall was stained yellow. ( $\times 1200)$.$B , Longitudinal$ section of part of a pitted vessel of Nicotiana; a portion of the intact oblique end wall and the closing membranes of the bordered pits appear black. $(\times 540)$.$C , Longitudinal section$ of Cucurbita xylem showing the result of the tearing apart of parenchyma cells that occurred near an expanding vessel. $(\times 400$. 



Plate 4. Longitudinal sections of fully expanded vessel segments of $Z e a: A$, with secondary longitudinal walls and intact primary end wall; $B$, with disintegrating material in place of end wall. $C$ and $D$ show the appearance of the end wall mounted between crossed Nicol prisms: two peripheral anisotropic layers are separated from each other by isotropic material. The section in $C$ was treated with hot water for 15 minutes; the one in $D$ was stained with congo red; both were mounted in water. $($ All $\times 540$.) 